\title{
Effect of Timing and Rates of Nitrogen Application on Yield, Chemical Compositions, Pharmacologic Activities, and Cytotoxicity of Herbal Bush Tea (Athrixia phylicoides DC.)
}

\author{
Itani Tshivhandekano and Fhatuwani Nixwell Mudau ${ }^{1}$ \\ Department of Agriculture and Animal Health, University of South Africa, \\ Private Bag X6, Florida 1710, South Africa
}

\section{Thilivhali Emmanuel Tshikalange \\ Department of Plant Science, University of Pretoria, Private Bag X20, Hatfield 0028, South Africa}

Additional index words. antimicrobial activity, antioxidant activity, biomass, chemical composition, cytotoxicity

\begin{abstract}
Bush tea is a popular South African herbal and medicinal tea with the potential for commercialization. The objective of the study was to investigate the effects of different rates of applied nitrogen $(N)$ and timing (early and late) of $N$ application on yield, chemical composition, pharmacologic activity, and cytotoxicity of bush tea. Factorial treatments consisted of timed $N$ application rates $\left(0,75,150\right.$, and $\left.225 \mathrm{~kg} \cdot \mathrm{ha}^{-1}\right)$ for both early and late $\mathrm{N}$ application. The treatments were arranged in a randomized complete block design with five replicates. The results show a significant positive response of bush tea fresh and dry leaf and twig weight, chlorophyll, leaf tissue $\mathbf{N}$, total polyphenols, and total flavonoids in response to applied $\mathrm{N}$ rates, regardless of the timing of $\mathrm{N}$ application, reaching a maximum at $225 \mathrm{~kg} \cdot \mathrm{ha}^{-1}$ of $\mathrm{N}$. Later, regardless of the timing of $\mathrm{N}$ application, total tannins and total antioxidant activity increased with increasing applied $\mathrm{N}$ from 0 to $225 \mathrm{~kg} \cdot \mathrm{ha}^{-1}$, reaching a maximum of $150 \mathrm{~kg} \cdot \mathrm{ha}^{-1} \mathrm{~N}$. The results of this study suggest that, with the exception of antimicrobial activity, most of the parameters recorded increased with increasing rates of $\mathrm{N}$ applied. The results further denote that parameters recorded were consistently greater on early applied $\mathbf{N}$ compared with late applied N. However, there was no significant difference between the minimum inhibition concentration (MIC) and minimum microbicide concentration (MMC) of early and late applied N. Bush tea applied with $75 \mathrm{~N}$ and $150 \mathrm{~N}$ had a significant $\mathrm{MIC}$ value $\left(3.1 \mathrm{mg} \cdot \mathrm{mL}^{-1}\right)$ for Escherichia coli and Klebsiella pneumonia compared with $6.3 \mathrm{mg} \cdot \mathrm{mL}^{-1}$ reached at $225 \mathrm{~kg} \cdot \mathrm{ha}^{-1} \mathrm{~N}$. Among N rates applied, the MIC for Klebsiella oxytoca, Proteus vulgaris, Salmonella typhi, Serratia marcescence, and Staphylococcus aureus were not significantly different. Hence, $\mathrm{N}$ rates applied did not have a significant effect on bush tea MMC values of all microbial species tested. The cytotoxicity of bush tea leaf and twigs harvested from early and late $\mathbf{N}$ application were significantly reduced with increasing nitrogen levels reaching a maximum at $225 \mathrm{~kg} \cdot \mathrm{ha}^{-1}$. There was a wide variation of compounds despite rates of $\mathrm{N}$ applied as well as timing of application, with most compounds such as norfenfluramine, phytol, caryophyllene, propylene glycol, $\alpha$-copaene, and squalene detected in greater quantities.
\end{abstract}

Bush tea is a South African herbal tea with the potential for commercialization. The commercialization of bush tea is supported by a report of the toxicologic assessment of bush tea conducted by Chellan et al. (2008). They have reported widespread consumption

\footnotetext{
Received for publication 2 Mar. 2018. Accepted for publication 10 July 2018.

We gratefully acknowledge the financial support of the National Research Foundation, the Gauteng Department of Agriculture and Rural Development, and Stellenbosch University's Division of Research Development.

${ }^{1}$ Corresponding author. E-mail: mudaufn@unisa. ac.za.
}

of bush tea in South Africa. Mudau et al. (2007) also reported that commercialization of bush tea can provide a healthy beverage alternative to caffeine-containing teas. The plant is used popularly as an herbal tea and a medicinal plant for the treatment of different ailments (Nchabeleng et al., 2013).

Naturally, bush tea grows at different altitudes with different rainfall regimes and soil characteristics (Nchabeleng et al., 2012). Therefore, to achieve good-quality bush tea, it is important to study the nutritional requirement of field-grown bush tea plants. Fertilizers play a critical role in determining horticultural crop yield, quality, and nutritional content (Martinez-Ballestra et al., 2008). In general, all major quality attributes in horticultural crops, including visual quality and taste, are influenced directly by $\mathrm{N}$ availability (Locascio et al., 1984). In green tea production, fertilizer is a major agro-input for the production of high-yield and high-quality tea (Woldegebriel, 2007). Fertilizers improve the nutritional status of both soil and plants (Njogu et al., 2014). Because tea production is a perennial monoculture, a well-balanced fertilizer is necessary throughout the year (Hamid et al., 2014).

The production of secondary metabolites in medicinal plants has been reported to be influenced by genetics and cultivation conditions, such as climate, plant density, and the use of fertilizers (Baranauskiene et al., 2003). Among fertilizers, $\mathrm{N}$ is the most important nutrient for crop production because it promotes both yield and quality of plant secondary metabolites (Sifola and Barbieri, 2006). The reason for extensive $\mathrm{N}$ application is that the quality of green tea is known to correlate directly with the concentration of primary compounds related to $\mathrm{N}$ application (Watanabe, 1995). In addition, $\mathrm{N}$ is a wellknown essential element for plant growth and it plays a regulatory role in the synthesis of secondary metabolites, such as phenolic compounds (Ruan et al., 2010). Conversely, Bryant et al. (1983) hypothesized that high $\mathrm{N}$ levels in plant tissues contribute to the formation of more amino acids and proteins for growth in relation to defense compounds such as secondary metabolites.

Previous studies demonstrated that earlyapplied $\mathrm{N}$ levels ranging from 75 to 225 $\mathrm{kg} \cdot \mathrm{ha}^{-1}$ improved growth and quality in cultivated bush tea (Tshivhandekano et al., 2017). However, data are lacking to demonstrate the effect of timing and rates of $\mathrm{N}$ application on bush tea. Thus, this study aimed at investigating the effect of applied $\mathrm{N}$ rates and timing of $\mathrm{N}$ application on yield, chemical compositions, pharmacologic activity, and cytotoxicity of bush tea.

\section{Materials and Methods}

Experimental site. The experiments were conducted at the Tshwane University of Technology (TUT) experimental farm, which is situated north of Pretoria (lat. $25^{\circ} 36^{\prime} 03.2^{\prime \prime} \mathrm{S}$; long. $\left.28^{\circ} 13^{\prime} 30.9^{\prime \prime} \mathrm{E}\right)$. The trials were conducted beginning in spring (Sept. 2016) to the end of Nov. 2016. The plants were allowed to resprout and the trial was repeated beginning in the summer (Dec. 2016) until the end of the summer season (Feb. 2017). The resprouted shoots were fertilized in the same manner as the initial plants. Weather data are presented in Table 1; this was the best time to cultivate bush tea in South Africa (Mudau et al., 2006, 2007).

Five soil samples were collected per horizon ( $\mathrm{A}$ and $\mathrm{B}$ ) from different spots on the plot the trial was conducted. Each soil sample collected was packed separately in different marked brown paper bags. The initial soil chemical analyses were conducted using the procedure described by Hanlon et al. (1994). The soil contained $0.001 \mathrm{mg} \cdot \mathrm{kg}^{-1}$ nitrate-N. 
Other soil chemical characteristics are presented in Table 2.

Experimental design and treatment details. Factorial treatments consisted of timed $\mathrm{N}$ application rates $\left(0,75,150\right.$, and $\left.225 \mathrm{~kg} \cdot \mathrm{ha}^{-1}\right)$ for both early and late $\mathrm{N}$ application. Applied $\mathrm{N}$ rates were $0,75,150$, and $225 \mathrm{~kg} \cdot \mathrm{ha}^{-1}$ per plot of 36 plants spaced at $0.5 \times 0.5 \mathrm{~m}$. The $\mathrm{N}$ rates were timely (early and late) manually broadcasted once off. Early (3 weeks after plant establishment) and late (6 weeks after plant establishment) $\mathrm{N}$ application was conducted in a randomized complete block design with five single plants per treatment replicated five times. Limestone ammonium nitrate $(28 \% \mathrm{~N})$ was used as an $\mathrm{N}$ fertilizer source. All plants received $75 \mathrm{~kg} \cdot \mathrm{ha}^{-1}$ phosphorus $(\mathrm{P})$ and $45 \mathrm{~kg} \cdot \mathrm{ha}^{-1}$ potassium $(\mathrm{K})$. The fertilizer source for $\mathrm{P}$ was single superphosphate $(10.5 \%)$; for $\mathrm{K}$, it was potassium chloride (50\%) [Ocean Agriculture (PTY) LTD, Muldersdrift, South Africa]. Micronutrients were foliar applied as recommended by Maedza et al. (2017). Two liters of water per plant was applied every third day using a drip irrigation system.

Plant material. The plant materials were collected from Haenerstburg (lat. 23 $3^{\circ} 56^{\prime} \mathrm{S}$; long. $29^{\circ} 54^{\prime} \mathrm{E}$; $890 \mathrm{~m}$ a.s.1.) in Limpopo Province, South Africa. Plants were propagated by using cuttings as described by Mudau et al. (2006). Bush tea cuttings 7 to $8 \mathrm{~cm}$ long were planted as described by Maudu et al. (2012), with sand used as the growth media. The cuttings were placed on the mist bed and allowed to sprout and root. The well-matured bush tea that hardened in the shade nets after propagation were later transplanted to the TUT experimental farm for the open field trial, using a plant spacing of $0.5 \times 0.5 \mathrm{~m}$.

Parameters recorded. Biomass (fresh and dry weight of leaf and twigs), chlorophyll content, leaf tissue $\mathrm{N}$, total polyphenols, total flavonoids, total tannins, antioxidant activity, antimicrobial activity, cytotoxicity, and detected compounds were documented.

Determination of chlorophyll content. Chlorophyll was measured once every month during the growing seasons with a portable Minolta chlorophyll meter (SPAD-502; Spectrum Technologies, Inc., Plainfield, IL).
Determination of fresh weight and dry weight. The average fresh and dry weights were determined used standard level precision balances. Fresh weight was measured immediately after harvest whereas dry weight was measured after 2 weeks of freeze drying.

Harvest and extraction of bush tea leaf and twig samples. The bush tea leaves and twigs were harvested using the current traditional method of cutting the plant from the stem to allow resprouting. The bush tea leaves and twigs from both early and late applied $\mathrm{N}$ plots were all harvested at the end of spring (Nov. 2016) and the end of summer (end of Feb. 2017). During harvest, the leaves and twigs were packed in marked brown paper bags. After harvest, bush tea leaves and twigs were transported immediately to the science campus of the University of South Africa in Florida (lat. 5.26 $6^{\prime} 501^{\prime \prime} \mathrm{S}$, long. $27^{\circ} 54^{\prime} 113^{\prime \prime} \mathrm{E}$ ), where they were weighed and freeze-dried for 2 weeks. One hundred grams of blended leaf materials was soaked in 150 $\mathrm{mL}$ ethanol and shaken at room temperature for $24 \mathrm{~h}$. The ethanol supernatant was filtered and then evaporated on a rotary evaporator under reduced pressure at $37^{\circ} \mathrm{C}$. The extract was stored in the cold room at $5{ }^{\circ} \mathrm{C}$, after which it was subjected to total polyphenol, total flavonoid, total tannin, antioxidant activity, antimicrobial activity, and cytotoxicity analyses.

Leaf and twig tissue $N$ analyses. The freeze-dried bush tea leaves and twigs harvested from both early and late applied $\mathrm{N}$ were finely ground to pass through a 20 -mesh screen. A sample of $0.2 \mathrm{~g}$ was digested at $37^{\circ} \mathrm{C}$ for $1 \mathrm{~h}$ in $100-\mathrm{mL}$ tubes containing 4 $\mathrm{mL}$ concentrated sulfuric acid, $2 \mathrm{~mL} 30 \%$ hydrogen peroxide, and $2.5 \mathrm{~g}$ of catalyst, which was comprised of a powdered mixture of $15 \mathrm{~g}$ copper sulfate, $250 \mathrm{~g}$ potassium sulfate, and stearic acid (Anon, 1972). After digestion, $100 \mathrm{~mL}$ distilled water was added to each sample and the hydrated samples were filtered through Whatman ${ }^{\circledR}$ No. 2 filter paper. Filtered samples were bottled and stored at $-20{ }^{\circ} \mathrm{C}$ before analysis. Nitrogen concentrations were determined in thawed samples using an Auto-Analyser (Anon,

Table 1. Weather data for 2016-17 at the Tshwane University of Technology experimental farm, Pretoria, Gauteng Province, South Africa.

\begin{tabular}{lcccc}
\hline & \multicolumn{2}{c}{ Avg temperature $\left({ }^{\circ} \mathrm{C}\right)$} & & \\
\cline { 2 - 3 } Month (2016-17) & Maximum & Minimum & Avg relative humidity (\%) & Avg rainfall (mm) \\
\hline Sept. & 28.21 & 8.96 & 42.99 & 37.65 \\
Oct. & 29.84 & 13.27 & 49.49 & 58.13 \\
Nov. & 29.43 & 15.21 & 57.48 & 66.15 \\
Dec. & 29.6 & 16.3 & 60.93 & 106.95 \\
Jan. & 29.65 & 17 & 66.15 & 157.76 \\
Feb. & 30.13 & 16.52 & 64.19 & 87.08 \\
\hline
\end{tabular}

1972) connected to a Sanplus Segmented Flow Analysis System (Skalar, Netherlands) and were expressed as percent $\mathrm{N}$ dry weight

Determination of total polyphenol content. The total polyphenol content was determined by colorimetric assay (Mohammed and Manan, 2015). Bush tea leaf and twig extracts $(200 \mu \mathrm{L})$ was added to $800 \mu \mathrm{L}$ distilled water followed by $100 \mu \mathrm{L}$ FolinCiocalteu. The mixtures were incubated for $3 \mathrm{~h}$ at room temperature. A total of $300 \mu \mathrm{L}$ sodium carbonate $\left(\mathrm{Na}_{2} \mathrm{CO}_{3}\right) \quad(20 \% \quad \mathrm{w} / \mathrm{v})$ was added into the mixture and incubated for $2 \mathrm{~h}$ in the dark at room temperature. After $2 \mathrm{~h}$, the absorbance was recorded with a Metertech ultraviolet/VIS SP8001 spectrometer (Metertech, Taipei, Taiwan) at $765 \mathrm{~nm}$. A blank was prepared with distilled water. A gallic acid standard curve was prepared from 0 to $200 \mathrm{mg} \cdot \mathrm{L}^{-1}$ using the same method. The total phenolic contents were calculated from the prepared standard curve of $0-200 \mathrm{mg}$ gallic acid equivalent (GAE) per gram dry matter; total phenolic content was expressed in milligrams GAE equivalent to $g$ dry matter.

Determination of total flavonoid content. Flavonoid content was analyzed by colorimetric analysis (Mohammed and Manan, 2015). A mixture of $200 \mu \mathrm{L}$ bush tea leaf and twig extracts was added to $150 \mu \mathrm{L}$ sodium nitrite $(5 \% \mathrm{w} / \mathrm{v})$ and was incubated for $6 \mathrm{~min}$ at room temperature. After incubation, $150 \mu \mathrm{L}$ aluminum chloride hexahydrate $(10 \% \mathrm{w} / \mathrm{v})$ was added and incubated for another $6 \mathrm{~min}$ at room temperature. After the second incubation, $800 \mu \mathrm{L}$ sodium hydroxide $(\mathrm{NaOH} ; 10 \% \mathrm{w} / \mathrm{v})$ solution was added and incubated at room temperature for $15 \mathrm{~min}$. For a negative control, distilled water replaced the extract. Absorbance was read by using a Metertech ultraviolet/VIS SP8001 spectrometer at $510 \mathrm{~nm}$. Before total flavonoid content was determined, a standard curve of quercetin dissolved in $80 \%$ ethanol was prepared from 0 to $500 \mu \mathrm{g} \cdot \mathrm{mL}^{-1}$. Total flavonoid was expressed in milligrams quercetin equivalent gram dry matter.

Determination of total tannin content. The total tannin content was determined by the Folin-Ciocalteu assay method (Mohammed and Manan, 2015). Bush tea leaf and twig extracts of $100 \mu \mathrm{L}$ were added to $750 \mu \mathrm{L}$ distilled water, $500 \mu \mathrm{L}$ Folin-Ciocalteu reagents, and $1000 \mu \mathrm{L} 35 \% \quad \mathrm{Na}_{2} \mathrm{CO}_{3}$. The mixture was diluted with distilled water to $10 \mathrm{~mL}$ and then shaken. After shaking, the mixture was incubated for $30 \mathrm{~min}$ at room temperature and subsequently read at $725 \mathrm{~nm}$ with a Metertech ultraviolet/VIS SP8001 spectrometer. Gallic acid standard solutions were prepared using the same method. Distilled water replaced the extract and was used as a negative control. The total tannin content

Table 2. Chemical characteristics of soils collected from the Tshwane University of Technology experimental farm during the $2016-17$ growing season.

\begin{tabular}{|c|c|c|c|c|c|c|c|c|c|c|c|c|c|}
\hline Horizon & $\begin{array}{c}\mathrm{Mg} \\
\left(\mathrm{cmol}^{\circ} \mathrm{kg}^{-1}\right)\end{array}$ & $\begin{array}{c}\mathrm{CEC} \\
\left(\mathrm{cmol}^{\circ} \mathrm{kg}^{-1}\right)\end{array}$ & $\begin{array}{c}\mathrm{P} \\
\left(\mathrm{mg} \cdot \mathrm{kg}^{-1}\right)\end{array}$ & $\begin{array}{c}\mathrm{pH} \\
\left(\mathrm{H}_{2} \mathrm{O}\right)\end{array}$ & $\begin{array}{c}\text { Org } \\
\text { C }(\%)\end{array}$ & $\begin{array}{c}\mathrm{Fe} \\
\left(\mathrm{mg} \cdot \mathrm{kg}^{-1}\right)\end{array}$ & $\begin{array}{c}\mathrm{Mn} \\
\left(\mathrm{mg} \cdot \mathrm{kg}^{-1}\right)\end{array}$ & $\begin{array}{c}\mathrm{Cu} \\
\left(\mathrm{mg} \cdot \mathrm{kg}^{-1}\right)\end{array}$ & $\begin{array}{c}\mathrm{Zn} \\
\left(\mathrm{mg} \cdot \mathrm{kg}^{-1}\right)\end{array}$ & $\mathrm{Cl}(\%)$ & $\begin{array}{c}\mathrm{Na} \\
\left(\mathrm{cmol} \cdot \mathrm{kg}^{-1}\right)\end{array}$ & $\begin{array}{c}\mathrm{K} \\
\left(\mathrm{cmol} \cdot \mathrm{kg}^{-1}\right)\end{array}$ & $\begin{array}{c}\mathrm{Ca} \\
\left(\mathrm{cmol} \cdot \mathrm{kg}^{-1}\right)\end{array}$ \\
\hline $\mathrm{A}, 0-250 \mathrm{~mm}$ & 5.346 & 26.007 & 1.12 & 7.32 & 1.3 & 10.54 & 12.14 & 2.37 & 3.1 & 42.2 & 0.285 & 0.776 & 11.991 \\
\hline $\mathrm{B}, 250-700 \mathrm{~mm}$ & 5.25 & 24.357 & 0.43 & 7.7 & 0.79 & 12.5 & 14.46 & 2.08 & 1.79 & 51.1 & 0.294 & 0.21 & 10.881 \\
\hline
\end{tabular}

$\mathrm{CEC}=$ cation exchange capacity; Org = organic 
was calculated based on the prepared standard curve with $0-100 \mathrm{mg}$ gallic acid and presented as GAE per gram dry matter.

Determination of antioxidant activity. The method described by Du Toit et al. (2001) was used to determine the total antioxidant activity of bush tea leaf and twig extracts. Vitamin C was used as the standard. The plant extract $(2 \mathrm{mg})$ was dissolved in $200 \mu \mathrm{L}$ ethanol to yield a stock concentration of $10 \mathrm{mg} \cdot \mathrm{mL}^{-1}$; whereas $2 \mathrm{mg}$ vitamin $\mathrm{C}$ was dissolved in $1 \mathrm{~mL}$ ethanol to give a stock concentration of $2 \mathrm{mg} \cdot \mathrm{mL}^{-1}$ to serve as the positive control. A solution of 1,1-diphenyl2-picrylhydrazyl was prepared by dissolving $20 \mathrm{mg}$ in $500 \mathrm{~mL}$ ethanol to yield a stock concentration of $0.04 \mathrm{mg} \cdot \mathrm{mL}^{-1}$. All samples were tested in triplicate using 96-well microplates. The startup concentration for the test samples in the first row was $500 \mu \mathrm{g} \cdot \mathrm{mL}^{-1}$, which was a composition of distilled water and the extract, whereas the positive control (vitamin C) was a mixture of distilled water and vitamin $\mathrm{C}$ with a final concentration of $100 \mu \mathrm{g} \cdot \mathrm{mL}^{-1}$ (in the first row). Blank controls were prepared by adding ethanol to distilled water; negative controls contained test samples and distilled water. These were serially diluted from the first row to the last row, and 1-diphenyl-2-picrylhydrazyl was added into all the wells except the negative controls. The plates were covered in foil and incubated for $30 \mathrm{~min}$. The absorbencies were read with an enzyme-linked immunosorbent assay (ELISA) plate reader (KC junior version 4.0; Bio Tek Instruments) at $515 \mathrm{~nm}$, and the absorbance values were analyzed with Graph Pad Prism 4.0. For antioxidant activity analyses, the sum of squares was partitioned into linear or quadratic polynomial orthogonal contrasts by using the Statistical Analyses System, version 9.4 (SAS Institute, Cary, NC).

Antimicrobial assay. The microdilution technique of using 96-well microplates, as described by Eloff (1998), was used to obtain the MIC (measured in milligrams per milliliter) and MMC (measured in milligrams per milliliter) values of the bush tea leaf and twig ethanol extracts against the selected microorganisms under study. MIC is defined as the greatest dilution or least concentration of the extracts that inhibit growth of organisms (Sen and Batra, 2012). MMC was recorded as the lowest concentration of extract that inhibited $100 \%$ growth of microorganisms (Cohen et al., 1998). Extracts were serially diluted in the 96-well plate and the final concentration of extracts and ciprofloxacin (positive control) ranged from 0.196 to $25 \mathrm{mg} \cdot \mathrm{mL}^{-1}$. The 24-h-old microorganisms were added into the 96-well plates and incubated for $24 \mathrm{~h}$ at $37^{\circ} \mathrm{C}$. MIC was determined by adding $40 \mu \mathrm{L}$ of $0.2 \mathrm{mg} \cdot \mathrm{mL}^{-1} p$-iodonitrotetrazolium violet (Sigma-Aldrich, South Africa) to microplate wells which were then incubated at $37^{\circ} \mathrm{C}$ for $24 \mathrm{~h}$. After incubation, MMC was tested by adding $50 \mu \mathrm{L}$ of the suspensions from the wells, which did not show any growth after incubation during MIC assays, to $150 \mu \mathrm{L}$ fresh broth. These suspensions were reincubated at $37^{\circ} \mathrm{C}$ for another $24 \mathrm{~h}$. Last,
$40 \mu \mathrm{L}$ of $0.2 \mathrm{mg} \cdot \mathrm{mL}^{-1} p$-iodonitrotetrazolium violet was added to the microplate wells and incubated at $37{ }^{\circ} \mathrm{C}$ for $2 \mathrm{~h}$ to complete the MMC concentration assay.

Microbial species used. The microbial strains used were the Gram-negative bacteria Escherichia coli (ATCC 8739), Klebsiella oxytoca (ATCC 49131), Proteus vulgaris (ATCC 6380), Serratia marcescens (ATCC 13880), Salmonella typhi (ATCC 14028), and Klebsiella pneumonia (ATCC 13883); the Gram-positive bacteria were Bacillus cereus (ATCC 11778) and Staphylococcus aureus (ATCC 25931). The selected microorganisms were grown in casein-peptone soy agar medium (Merck SA (Pty) Ltd., Modderfontein, Johannesburg). The McFarland standard was used to record the bacterial concentration of $4 \times 10^{7}$ (Dey et al., 2010).

XTT cytotoxicity assay. The cytotoxicity of bush tea leaf and twig extracts were tested on human embryonic kidney 293 cells. One hundred microliters of human embryonic kidney cell suspensions $\left(1 \times 10^{5}\right.$ cells $\left./ \mathrm{mL}\right)$ were added to the inner wells of a 96-well plate; $200 \mu \mathrm{L}$ of incomplete medium [Dulbecco's Modified Eagle's Medium (DMEM)] was added to the outer wells. The plates were incubated for $24 \mathrm{~h}$ to allow the cells to attach to the base of the plate. Serial dilution of the plant extracts [already dissolved in dimethyl sulfoxide (DMSO)], the positive control (actinomycin D) and negative (vehicle) control DMSO with the complete medium $(10 \%$ fetal bovine serum and DMEM) and penicillium/ streptomycin were carried out in a 24-well plate to give eight different concentrations of each sample and a final volume of $1 \mathrm{~mL} /$ well. One hundred microliters of each concentration from the 24-well plate were added to the 96-well plate in triplicate, and there was a triplicate medium control and a DMSO control for each extract. A reference plate was prepared to account for the color of the plant extracts. This plate contained the plant extracts and medium in duplicate but no cells. The plates were incubated for $72 \mathrm{~h}$, after which $50 \mu \mathrm{L}$ XTT [2,3-bis-(2-methoxy-4-nitro-5sulfophenyl)-2H-tetrazolium-5-carboxanilide] reagent from Roche Diagnostics $\mathrm{GmbH}$ (Randburg, Johannesburg) was added to all the wells and they were incubated for about $2 \mathrm{~h} 30 \mathrm{~min}$. After incubation, the plates were read on an ELISA microplate reader with $\mathrm{KC}$ Junior version 4.0 software to read the absorbance at $450 \mathrm{~nm}$ and $690 \mathrm{~nm}$ as the reference wavelengths. Graph Pad Prism 4.0 was used to analyze the data.

Gas chromatography linked to mass spectrometry. Bush tea samples (one leaf per sample) were analyzed using headspace solid-phase microextraction gas chromatography linked to mass spectrometry using the method of Musarurwa et al. (2010), but oven ramping temperatures and injection ratios were modified. The headspace solid-phase microextraction of leaves were performed with Supelco SPME fibers [DVB/Carboxen/ PDMS, StableFlex (Supelco)]. Leaves were placed directly into a $20-\mathrm{mL}$ headspace vial, then sealed with an aluminum-coated silicone rubber septum. Volatiles were extracted at $70^{\circ} \mathrm{C}$ for $15 \mathrm{~min}$. Gas chromatography was performed with a Waters GCT Premier AS 2000 coupled to a mass spectrometer equipped with an HP5 column $(30 \mathrm{~m}, 0.25 \mathrm{~mm}$ i.d., $0.25 \mu \mathrm{L}$ film thicknesses). Temperatures were set at $250{ }^{\circ} \mathrm{C}$ for both the injection (splitless injection) and the ion source temperature. Helium was used as the carrier gas $\left(1 \mathrm{~mL} \cdot \mathrm{min}^{-1}\right)$. The temperature ramp regime was initiated by heating at $5{ }^{\circ} \mathrm{C}$ for $3 \mathrm{~min}$, followed by an oven ramp to $142{ }^{\circ} \mathrm{C}$ at $5{ }^{\circ} \mathrm{C} \cdot \mathrm{min}^{-1}$, and a second ramp of $1{ }^{\circ} \mathrm{C} \cdot \mathrm{min}^{-1}$ up to $240{ }^{\circ} \mathrm{C}$. A mass scanning range of 40 to $550 \mathrm{~m} \cdot \mathrm{z}^{-1}$ (perfluorotrin-butylamine as mass reference) was used, and mass spectra were recorded at two scans. The National Institute of Standards and Technology library was used for the tentative identification of compounds.

Statistical analyses. Data were subjected to analysis of variance by using the general linear model of the Statistical Analyses System, version 9.4 (SAS Institute). Treatment sum of squares was partitioned orthogonally to determine the effects of control vs. treatment and early treatment vs. late treatment. In both seasons, data were pooled and mean separation was done using Duncan's multiple range test. For gas chromatography linked to mass spectrometry, Kovats indices were calculated from an alkane series to verify compound names.

\section{Results}

Biomass (fresh and dried weight). The results in Table 3 demonstrated that, regardless of the timing of $\mathrm{N}$ application, as $\mathrm{N}$ application rates increased from 0 to $225 \mathrm{~kg} \cdot \mathrm{ha}^{-1}$, bush

Table 3. Bush tea mean fresh weight, dry weight, and leaf chlorophyll value in response to applied $\mathrm{N}$ rates and timing of $\mathrm{N}$ application.

\begin{tabular}{lcrr}
\hline Applied N (kg.ha $\left.{ }^{-1}\right)$ & Chlorophyll (SPAD value) & Fresh wt $(\mathrm{g})$ & Dry wt $(\mathrm{g})$ \\
\hline Early application & & & $33 \mathrm{~d}$ \\
0 & $34.57 \mathrm{f}$ & $85 \mathrm{f}$ & $60 \mathrm{c}$ \\
75 & $42.33 \mathrm{~d}$ & $110 \mathrm{e}$ & $103 \mathrm{a}$ \\
150 & $47.23 \mathrm{~b}$ & $170 \mathrm{a}$ & $108 \mathrm{a}$ \\
225 & $50.03 \mathrm{a}$ & $105 \mathrm{e}$ & $42 \mathrm{c}$ \\
Late application & & $130 \mathrm{~d}$ & $55 \mathrm{~cd}$ \\
75 & $39.96 \mathrm{e}$ & $147 \mathrm{c}$ & $82 \mathrm{~b}$ \\
150 & $45.27 \mathrm{c}$ & 0.0001 & 0.0001 \\
225 & $47.87 \mathrm{~b}$ & 0.0001 & 0.0001 \\
Contrast: Control vs. treatment & 0.0001 & 0.0001 &
\end{tabular}

Means with the same letters in a column are not significantly different at $P<0.0001$. 
tea leaf and twig fresh and dry weights increased significantly, reaching a maximum at $225 \mathrm{~kg} \cdot \mathrm{ha}^{-1} \mathrm{~N}$. In addition, with the exception of the fresh weight of bush tea treated with $75 \mathrm{~kg} \cdot \mathrm{ha}^{-1} \mathrm{~N}$, early $\mathrm{N}$ applied bush tea resulted in a significantly greater biomass compared with late applied N. A strong correlation was recorded between fresh weight and dry weight with leaf and twig tissue $\mathrm{N}$, total polyphenol content, total flavonoid content, total tannin content, total antioxidant activity, and cytotoxicity of both early and late $\mathrm{N}$ applied bush tea (Tables 4 and 5). However, there was no relationship $(<50 \%)$ between fresh weight and antioxidant activity, as well as dry weight and antioxidant activity on late $\mathrm{N}$ applied bush tea.

Chlorophyll. The results of chlorophyll (SPAD values) presented in Table 3, show that, regardless of the timing of $\mathrm{N}$ application, as applied $\mathrm{N}$ rates increased from 0 to $225 \mathrm{~kg} \cdot \mathrm{ha}^{-1}$, chlorophyll values also increased significantly, reaching a maximum at 225 $\mathrm{kg} \cdot \mathrm{ha}^{-1}$. Bush tea chlorophyll was significantly greater on early $\mathrm{N}$ applied rates compared with late $\mathrm{N}$ rates applied. Chlorophyll of both early and late $\mathrm{N}$ applied bush tea had a strong relationship with leaf and twig tissue $\mathrm{N}$, fresh weight, dry weight, polyphenol content, flavonoid content, tannin content, and cytotoxicity (Tables 4 and 5). There was a weak relationship between chlorophyll and antioxidant activities in bush tea leaves and twigs.

Leaf tissue $N$. The percentage of leaf and twig tissue $\mathrm{N}$ of both early and late $\mathrm{N}$ applied bush tea increased with increasing $\mathrm{N}$ rates from 0 to $225 \mathrm{~kg} \cdot \mathrm{ha}^{-1}$ (Table 6). The bush tea leaf and twig tissue $\mathrm{N}$ of both early and late applied $\mathrm{N}$ increased significantly with increasing rates of $\mathrm{N}$, reaching a maximum at an $\mathrm{N}$ rate of $225 \mathrm{~kg} \cdot \mathrm{ha}^{-1}$ for early applied $\mathrm{N}$ and $150 \mathrm{~kg} \cdot \mathrm{ha}^{-1}$ for late applied N. However, early applied $\mathrm{N}$ to bush tea leaves and twigs had significantly greater tissue $\mathrm{N}$ compared with late applied $\mathrm{N}$ bush tea. The results denote that early applied $\mathrm{N}$ rates increased significantly bush tea leaf and twig tissue $\mathrm{N}$ compared with late applied $\mathrm{N}$ rates. The bush tea leaf and twig tissue $\mathrm{N}$ of both early and late applied $\mathrm{N}$ exhibited a strong relationship with chlorophyll, fresh weight, dried weight, polyphenol content, flavonoid content, tannin content, antioxidant activity, and cytotoxicity (Tables 4 and 5).

Polyphenol content. Regardless of the timing of $\mathrm{N}$ application, as applied $\mathrm{N}$ levels increased from 0 to $225 \mathrm{~kg} \cdot \mathrm{ha}^{-1}$, the production of bush tea total polyphenols (Table 6) increased significantly, reaching a maximum at $225 \mathrm{~kg} \cdot \mathrm{ha}^{-1}$. The results suggest that bush tea from early applied $\mathrm{N}$ levels had a significantly greater total polyphenol content compared with late applied $\mathrm{N}$ rates. The results further suggest that bush tea total polyphenol content had a strong relationship with leaf and twig tissue $\mathrm{N}$, chlorophyll, fresh weight, dry weight, flavonoid content, tannin content, and cytotoxicity (Tables 4 and 5). However, bush tea total polyphenol content exhibited weak relationships with tannin content and antioxidant activity in early applied N, and in antioxidant activity in late applied $\mathrm{N}$.

Flavonoid content. The bush tea total flavonoid content of both early and late applied $\mathrm{N}$ increased with increasing applied $\mathrm{N}$ from 0 to $225 \mathrm{~kg} \cdot \mathrm{ha}^{-1}$, reaching a maximum at $225 \mathrm{~kg} \cdot \mathrm{ha}^{-1} \mathrm{~N}$ (Table 6). The results

Table 4. Correlations of bush tea parameters recorded for early applied N.

\begin{tabular}{|c|c|c|c|c|c|c|c|c|}
\hline & $\begin{array}{l}\text { Leaf tissue } \\
\mathrm{N}(\%)\end{array}$ & $\begin{array}{c}\text { Chlorophyll } \\
\text { (SPAD values) }\end{array}$ & $\begin{array}{l}\text { Fresh } \\
\text { wt }(g)\end{array}$ & $\begin{array}{c}\text { Dry } \\
\text { wt }(\mathrm{g})\end{array}$ & $\begin{array}{l}\text { Total polyphenols } \\
\text { (GAE/g dry matter) }\end{array}$ & $\begin{array}{l}\text { Total flavonoids } \\
\text { (QE/g dry matter) }\end{array}$ & $\begin{array}{c}\text { Total tannins } \\
\text { (GAE/g dry matter) }\end{array}$ & $\begin{array}{c}\text { Total antioxidant } \\
\text { activity }\left(\mathrm{IC}_{50}\right)\end{array}$ \\
\hline Chlorophyll & $0.96^{* *}$ & & & & & & & \\
\hline Fresh weight & $0.91 * *$ & $0.97 * *$ & & & & & & \\
\hline Dried mass & $0.85^{* *}$ & $0.94 * *$ & $0.99 * *$ & & & & & \\
\hline Polyphenols & $0.94 * *$ & $0.99 * *$ & $0.92 * *$ & $0.88 * *$ & & & & \\
\hline Flavonoids & $0.99 * *$ & $0.98 * *$ & $0.93 * *$ & $0.87 * *$ & $0.98 * *$ & & & \\
\hline Tannins & $0.78^{*}$ & $0.62 *$ & $0.67 *$ & $0.60 *$ & 0.53 & $0.68 *$ & & \\
\hline Antioxidant & 0.59 & 0.52 & $0.67 *$ & $0.66^{*}$ & 0.38 & 0.50 & $0.88 * *$ & \\
\hline Cytotoxicity & $0.97 * *$ & $0.86 * *$ & $0.81 * *$ & $0.72 *$ & $0.84 * *$ & 0.93 & $0.86 * *$ & $0.61 *$ \\
\hline
\end{tabular}

Significant at $* P \leq 0.05$ or $* * P \leq 0.01$.

$\mathrm{GAE}=$ gallic acid equivalent; $\mathrm{QE}=$ quercetin equivalent.

Table 5. Correlations of bush tea parameters recorded for late applied N.

\begin{tabular}{|c|c|c|c|c|c|c|c|c|}
\hline & $\begin{array}{c}\text { Leaf tissue } \\
\mathrm{N}(\%)\end{array}$ & $\begin{array}{c}\text { Chlorophyll } \\
\text { (SPAD values) }\end{array}$ & $\begin{array}{l}\text { Fresh } \\
\text { wt }(g)\end{array}$ & $\begin{array}{c}\text { Dry } \\
\text { wt (g) }\end{array}$ & $\begin{array}{l}\text { Total polyphenols } \\
\text { (GAE/g dry matter) }\end{array}$ & $\begin{array}{l}\text { Total flavonoids } \\
\text { (QE/g dry matter) }\end{array}$ & $\begin{array}{c}\text { Total tannins } \\
\text { (GAE/g dry matter) }\end{array}$ & $\begin{array}{c}\text { Total antioxidant } \\
\text { activity }\left(\mathrm{IC}_{50}\right)\end{array}$ \\
\hline Chlorophyll & $0.96^{* *}$ & & & & & & & \\
\hline Fresh weight & $0.95 * *$ & $0.99 * *$ & & & & & & \\
\hline Dry weight & $0.85 * *$ & $0.92 * *$ & $0.95 * *$ & & & & & \\
\hline Polyphenols & $0.98 * *$ & $0.93 * *$ & $0.94 * *$ & $0.89 * *$ & & & & \\
\hline Flavonoids & $0.78^{*}$ & $0.88 * *$ & $0.91 * *$ & $0.99 * *$ & $0.83 * *$ & & & \\
\hline Tannins & $0.83 * *$ & $0.91 * *$ & $0.86^{* *}$ & $0.69 *$ & $0.72 *$ & $0.64 *$ & & \\
\hline Antioxidant & $0.68^{*}$ & 0.51 & 0.46 & 0.20 & 0.59 & 0.08 & $0.60 *$ & \\
\hline Cytotoxicity & $0.79 *$ & $0.87 * *$ & $0.81 * *$ & $0.63 *$ & $0.67 *$ & 0.58 & $1.00 * *$ & $0.61 *$ \\
\hline
\end{tabular}

Significant at $* P \leq 0.05$ or $* * P \leq 0.01$.

$\mathrm{GAE}=$ gallic acid equivalent; $\mathrm{QE}=$ quercetin equivalent.

Table 6. Response of bush tea leaf and twig tissue $\mathrm{N}$ and chemical compositions to applied $\mathrm{N}$ rates and the timing of $\mathrm{N}$ application.

\begin{tabular}{|c|c|c|c|c|c|}
\hline Applied N (kg.ha $\left.{ }^{-1}\right)$ & $\begin{array}{l}\text { Leaf tissue } \\
\mathrm{N}(\%)\end{array}$ & $\begin{array}{l}\text { Total polyphenols } \\
\text { (GAE/g dry matter) }\end{array}$ & $\begin{array}{l}\text { Total flavonoids } \\
\text { (QE/g dry matter) }\end{array}$ & $\begin{array}{c}\text { Total tannins } \\
\text { (GAE/g dry matter) }\end{array}$ & $\begin{array}{c}\text { Total antioxidant } \\
\text { activity }\left(\mathrm{IC}_{50}\right)\end{array}$ \\
\hline \multicolumn{6}{|l|}{ Early application } \\
\hline 0 & $1.67 \pm 0.24 \mathrm{~d}$ & $50.93 \pm 0.12 \mathrm{e}$ & $0.67 \pm 0.09 \mathrm{f}$ & $0.53 \pm 0.03 \mathrm{f}$ & $36.26 \pm 1.51 \mathrm{f}$ \\
\hline 75 & $1.95 \pm 0.27 \mathrm{~b}$ & $64.06 \pm 0.29 \mathrm{c}$ & $1.21 \pm 37 \mathrm{c}$ & $1.79 \pm 0.0 \mathrm{a}$ & $51.25 \pm 1.88 \mathrm{c}$ \\
\hline 150 & $2.06 \pm 0.18 \mathrm{a}$ & $65.14 \pm 0.47 b$ & $1.43 \pm 0.43 b$ & $1.99 \pm 0.01 \mathrm{a}$ & $55.32 \pm 0.89 \mathrm{a}$ \\
\hline 225 & $2.07 \pm 0.29 \mathrm{a}$ & $66.99 \pm 0.00 \mathrm{a}$ & $1.58 \pm 0.47 \mathrm{a}$ & $1.74 \pm 3.0 \mathrm{~b}$ & $51.91 \pm 9.76 \mathrm{c}$ \\
\hline \multicolumn{6}{|l|}{ Late application } \\
\hline 75 & $1.71 \pm 0.23 \mathrm{~d}$ & $50.95 \pm 0.49 \mathrm{e}$ & $0.74 \pm 0.22 \mathrm{e}$ & $1.42 \pm 0.01 \mathrm{e}$ & $37.71 \pm 2.05 \mathrm{e}$ \\
\hline 150 & $1.88 \pm 0.29 \mathrm{c}$ & $62.36 \pm 0.10 \mathrm{~d}$ & $0.79 \pm 0.28 \mathrm{~d}$ & $1.71 \pm 0.01 \mathrm{c}$ & $53.17 \pm 3.12 \mathrm{~b}$ \\
\hline 225 & $1.88 \pm 0.21 \mathrm{c}$ & $64.49 \pm 0.18 \mathrm{c}$ & $1.02 \pm 0.38 \mathrm{c}$ & $1.61 \pm 0.35 \mathrm{~d}$ & $39.16 \pm 0.69 \mathrm{e}$ \\
\hline Contrast: Control vs. treatments & 0.001 & 0.001 & 0.001 & 0.001 & 0.001 \\
\hline Contrast: Early vs. late treatments & 0.001 & 0.001 & 0.001 & 0.001 & 0.001 \\
\hline
\end{tabular}

Means with the same letters within the column are not significantly different using Duncan's multiple range test at $1 \%$.

$\mathrm{GAE}=$ gallic acid equivalent; $\mathrm{QE}=$ quercetin equivalent. 
demonstrate that early applied $\mathrm{N}$ rates increased significantly bush tea total flavonoid content compared with late applied $\mathrm{N}$ rates. Early $\mathrm{N}$ applied bush tea total flavonoid content had strong relationships with leaf and twig tissue $\mathrm{N}$, fresh weight, dry weight, total polyphenol content, total flavonoid content, tannin content, and cytotoxicity (Table 4). However bush tea total flavonoid content had a weak relationship with antioxidant activity. Similar results were recorded on late applied N bush tea, with additional weak relationships of bush tea total flavonoid content and cytotoxicity (Table 5).

Tannin content. Table 6 shows the results of total tannin content of bush tea leaves and twigs harvested from early and late applied $\mathrm{N}$. The results suggest that as $\mathrm{N}$ levels increased from 0 to $225 \mathrm{~kg} \cdot \mathrm{ha}^{-1}$, both early and late applied $\mathrm{N}$ total tannin content increased, reaching a maximum at $150 \mathrm{~kg} \cdot \mathrm{ha}^{-1} \mathrm{~N}$. It is evident that early $\mathrm{N}$ application increased bush tea leaf and twig total tannin content significantly compared with late applied $\mathrm{N}$. Early $\mathrm{N}$ applied bush tea total tannin content

Table 7. Bush tea cytotoxicity in relation to applied $\mathrm{N}$ rates and timing (early and late) of applied $\mathrm{N}$.

\begin{tabular}{lrr}
\hline Applied N $\left(\mathrm{kg} \cdot \mathrm{ha}^{-1}\right)$ & $\mathrm{IC}_{50}\left(\mu \mathrm{g} \cdot \mathrm{mL}^{-1}\right)$ & $R^{2}$ \\
\hline Early application & & \\
0 & $128.8 \mathrm{~b}$ & 0.94 \\
75 & $214.9 \mathrm{c}$ & 0.19 \\
150 & $237.1 \mathrm{a}$ & 0.63 \\
225 & $222.3 \mathrm{~b}$ & 0.76 \\
Actinomycin D & $93.2 \mathrm{~d}$ & 0.72 \\
Late application & & \\
75 & $213.8 \mathrm{c}$ & 0.23 \\
150 & $236.9 \mathrm{a}$ & 0.54 \\
225 & $221.5 \mathrm{~b}$ & 0.44 \\
Control vs. treatment & 0.0001 & \\
Early vs. late & 0.0001 & \\
\hline
\end{tabular}

Means with the same letters within the column are not significantly different when using Duncan's multiple range test at $1 \%$. had strong relationships with leaf and twig tissue $\mathrm{N}$, fresh weight, dry weight, total flavonoid content, total tannin content, total antioxidant activity, and cytotoxicity (Table 4 ). However early applied $\mathrm{N}$ bush tea total tannin content had a weak relationship with total polyphenol content. Late applied $\mathrm{N}$ bush tea total tannin content exhibited a strong relationship with all parameters recorded (Table 5).

Antioxidant activity. The total antioxidant activity of bush tea leaves and twigs harvested from early and late applied $\mathrm{N}$ results are presented in Table 6 . The results suggest that as the applied $\mathrm{N}$ rate increased from 0 to $225 \mathrm{~kg} \cdot \mathrm{ha}^{-1}$, early and late $\mathrm{N}$ application increased the total antioxidant activity significantly, reaching a maximum at $150 \mathrm{~kg} \cdot \mathrm{ha}^{-1} \mathrm{~N}$. The results suggest that early $\mathrm{N}$ application influenced total antioxidant activity significantly compared with late $\mathrm{N}$ application. Early $\mathrm{N}$ applied bush tea antioxidant activity had strong relationships with bush tea fresh weight, dried weight, and total tannin content (Table 4). Late applied $\mathrm{N}$ exhibited strong relationships with bush tea total antioxidant activity, leaf and twig tissue $\mathrm{N}$, and total tannin content (Table 5). Total antioxidant activity of early $\mathrm{N}$ applied bush tea had weak relationships with leaf and twig tissue $\mathrm{N}$, chlorophyll, total polyphenol content, and total flavonoid content. There were weak relationships between late applied $\mathrm{N}$ bush tea total antioxidant activity and chlorophyll, fresh weight, dry weight, total polyphenol content, and total flavonoid content.

Cytotoxicity. The cytotoxicity results (Table 7) are expressed as the maximum effective concentration required to inhibit $50 \%$ of the human embryonic kidney cells $\left(\mathrm{IC}_{50}\right.$, measured in micrograms per milliliter). Regardless of the timing of $\mathrm{N}$ level application, the cytotoxicity results of bush tea leaves and twigs suggests a significant increase in bush tea nontoxicity with increasing $\mathrm{N}$ rates. The nontoxicity of early and late $\mathrm{N}$ applied bush tea leaves and twigs reached a maximum at $150 \mathrm{~kg} \cdot \mathrm{ha}^{-1} \mathrm{~N}$. Therefore, the results imply that the nontoxicity of bush tea is not affected significantly by the timing of $\mathrm{N}$ application and the rates of $\mathrm{N}$ applied. Regardless of the timing of $\mathrm{N}$ application, bush tea noncytotoxicity had a strong interrelation with all parameters recorded (Tables 4 and 5).

Antimicrobial activity. MIC and MMC values of early and late $\mathrm{N}$ applied bush tea leaves and twigs were not significantly different. Table 8 presents MIC values of both early and late applied N; Table 9 presents MMC values of both early and late applied $\mathrm{N}$. Bush tea applied with $75 \mathrm{~N}$ and $150 \mathrm{~N}$ had a significant MIC value $\left(3.1 \mathrm{mg} \cdot \mathrm{mL}^{-1}\right)$ for $E$. coli and $K$. pneumonia compared with $6.3 \mathrm{mg} \cdot \mathrm{mL}^{-1}$ reached at $225 \mathrm{~kg} \cdot \mathrm{ha}^{-1} \mathrm{~N}$. Among applied N rates, MIC for $K$. oxytoca, $P$. vulgaris, $S$. typhi, $S$. marcescence, and $S$. aureus were not significantly different. Hence, applied $\mathrm{N}$ rates did not have a significant effect on bush tea MMC values of all microbial species tested. Bush tea MIC values ranged from 3.1 to $12.0 \mathrm{mg} \cdot \mathrm{mL}^{-1}$, whereas MMC values ranged from 6.3 to $25.0 \mathrm{mg} \cdot \mathrm{mL}^{-1}$ according to the microbial species used.

Compounds. Volatile compounds detected in bush tea from both early and late applied $\mathrm{N}$ by using gas chromatography linked to mass spectrometry varied (Table 10). Thus, it suggests that applied $\mathrm{N}$ and timing of $\mathrm{N}$ application influenced the variation of compounds detected as well as the relative abundance of compounds. Six compounds (phytol, caryophyllene, norfenfluramine, propylene glycol, $\alpha$-copaene, and squalene) were found to be significantly greater in the control, early applied nitrogen rate of $150 \mathrm{~kg} \cdot \mathrm{ha}^{-1}$, and late applied nitrogen of $75 \mathrm{~kg} \cdot \mathrm{ha}^{-1}$ and $225 \mathrm{~kg} \cdot \mathrm{ha}^{-1}$. It was observed that early applied $\mathrm{N}$ consistently had more compounds detected compared with the late $\mathrm{N}$ treatments.

\section{Discussion}

From this study, it was evident that early $\mathrm{N}$ application yielded significantly more bush tea biomass compared with late applied N. Nitrogen application increases overall plant growth (Wang et al., 2012). Similarly, $\mathrm{N}$ application increased bush tea biomass (Mudau et al., 2005). Nitrogen had been found to be the most important yield-increasing fertilizer, with the greatest yield of $872 \mathrm{~kg} \cdot \mathrm{ha}^{-1}$ obtained with $200 \mathrm{~kg} \cdot \mathrm{ha}^{-1} \mathrm{~N}$ applied in Camellia sinensis (Sitienei et al., 2013). However, proper $\mathrm{N}$ supply is required to optimize vegetative and reproductive growth and, consequently, overall yields (Lawlor, 2002).

High $\mathrm{N}$ availability for plants resulted in increased chlorophyll, photosynthesis, and primary growth of plant (Stefanelli et al., 2010). It was found that $\mathrm{N}$ application increased Labisia leaf chlorophyll (Ibrahim et al., 2011). Similarly, the level of chlorophyll $\mathrm{a}+\mathrm{b}$ in leaf of Lavandula angustifolia was reported to increase from 4.36 to $5.48 \mathrm{mg} \cdot \mathrm{g}^{-1}$, respectively, at the rates of 50 and $200 \mathrm{~kg} \cdot \mathrm{ha}^{-1}$ $\mathrm{N}$ (Biesiada et al., 2008). In addition, it was 


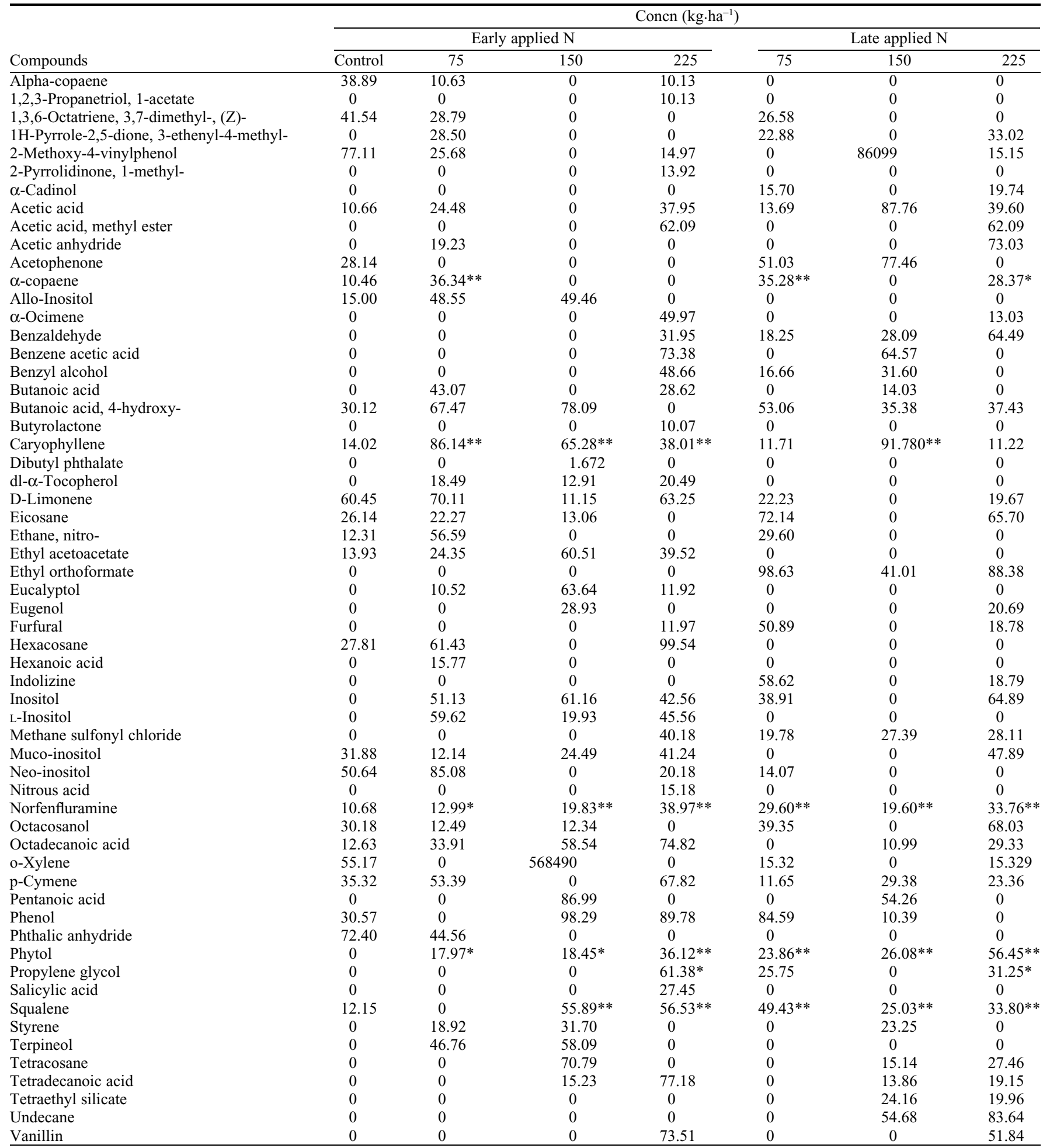

Relative abundance followed by asterisks are significant at $* P<0.05$ and $* * P<0.01$.

reported that as $\mathrm{N}$ levels increased in an ascending order of $0>90>180>270 \mathrm{~kg} \cdot \mathrm{ha}^{-1}$ $\mathrm{N}$, the net photosynthesis rate of Labisia pumila simultaneously increased steadily (Ibrahim et al., 2011). The results of the current study support the results of Ibrahim et al. (2011), who revealed that as $\mathrm{N}$ rate increased from 0 to $225 \mathrm{~kg} \cdot \mathrm{ha}^{-1} \mathrm{~N}$, leaf tissue $\mathrm{N}$ also increased considerably. The $\mathrm{N}$ uptake of Camellia sinensis increased with increased $\mathrm{N}$ application (Okano et al., 1997). Bush tea leaf tissue $\mathrm{N}$ increased with increased $\mathrm{N}$ (Mudau et al., 2005). The current results concur with the findings of Mudau et al. (2006), who reported a quadratic response of leave tissue $\mathrm{N}$ in potted bush tea cultivated under $50 \%$ shade net. In addition, Cechin and Fumis (2004) reported that increased $\mathrm{N}$ availability also resulted in greater sunflower leaf $\mathrm{N}$ content. According to Ibrahim et al. (2011), the increase in leaf tissue
$\mathrm{N}$ in response to increased $\mathrm{N}$ application might be the result of intensification of nitrate content in the leaf.

It has been reported that, regardless of season addition of $\mathrm{N}$ fertilizer, resulted in a significant $(P \leq 0.001)$ increased concentration of total polyphenols in bush tea leaf (Mudau et al., 2006). The increase in the concentration of total polyphenol mineral nutrition was also reported in tea (Owour, 
1989; Owour and Odhiambo, 1994). However, the results of the current study disagree with the observations made by Ibrahim et al. (2011), that total polyphenol content and total flavonoid content decreased in leaves with increasing $\mathrm{N}$ fertilization from 90 to 180 $\mathrm{kg} \cdot \mathrm{ha}^{-1} \mathrm{~N}$ and then $270 \mathrm{~kg} \cdot \mathrm{ha}^{-1} \mathrm{~N}$ by $42 \%$, $43 \%$, and $57 \%$, respectively, compared with non- $\mathrm{N}$ fertilization. In addition, a high $\mathrm{N}$ supply has been reported to decrease the concentrations of Chrysanthemum morifolium total flavonoids by $18 \%$ to $35 \%$ (Liu et al., 2010).

The current results exhibited a trend similar to that reported by Chabeli et al. (2008): Under $50 \%$ shade net, potted bush tea total tannin content increased with increasing $\mathrm{N}$ application, reaching a maximum at 300 $\mathrm{kg} \cdot \mathrm{ha}^{-1} \mathrm{~N}$. However, the difference is that, with the current results, $\mathrm{N}$ plateaued at 150 $\mathrm{kg} \cdot \mathrm{ha}^{-1}$, which is in contrast to the results of Chabeli et al. (2008), who reported that $\mathrm{N}$ plateaued at $300 \mathrm{~kg} \cdot \mathrm{ha}^{-1}$.

The current results of total antioxidant activity concurs with Mogotlane et al. (2007), who reported that the amount of total antioxidant activity in bush tea leaf was greatest at $300 \mathrm{~kg} \cdot \mathrm{ha}^{-1} \mathrm{~N}$. The nontoxicity results support the results reported previously by Mavundza et al. (2010), that quercetin compound extracted from bush tea exhibited minimal toxicity effect $\left(\mathrm{IC}_{50}\right.$ value, $81.38 \pm$ $\left.0.33 \mu \mathrm{g} \cdot \mathrm{mL}^{-1}\right)$. The $\mathrm{IC}_{50}$ value of all the bush tea extracts was reported to be greater than that of actinomycin $\mathrm{D}$, which was used as a positive control. Considering that the values of these extracts of bush tea were greater than that of actinomycin and greater than 100 $\mu \mathrm{g} \cdot \mathrm{mL}^{-1}$, bush tea should be considered nontoxic (Patel et al., 2010)

The relationship between bush tea leaf and twig $\mathrm{N}$ and total polyphenol content, total flavonoid content, total tannin content, total antioxidant activity, and cytotoxicity presents a sharp contrast with the carbon nutrient balance hypothesis. The hypothesis postulates that carbon-based compounds decrease with elevated nutrient availability (Bryant et al., 1983). It is hypothesized that plants respond to varying levels of resource availability in a physiologically passive manner driven by simple mass action (Hamilton et al., 2001; Nitao et al., 2002). Palumbo et al. (2007) argued that phenotypic plasticity in secondary metabolite production is influenced by resource availability and selective pressures that might be genetically regulated. On the other side, the current results are in support of the findings of Ibrahim et al. (2011), who reported a positive relationship between leaf tissue $\mathrm{N}$ and chlorophyll, photosynthesis, and biomass.

The results of this study are consistent with the results reported by Tshivhandekano et al. (2014) on wild harvested bush tea. They found that bush tea has antimicrobial activity in different zones (MIC range, 1.56-12.50 $\mathrm{mg} \cdot \mathrm{mL}^{-1}$; MMC range, $0.78-12.50 \mathrm{mg} \cdot \mathrm{mL}^{-1}$ ), depending on the microbial species tested. In contrast, Thembo et al. (2010) reported that an $\mathrm{MIC}$ value greater than $1.6 \mathrm{mg} \cdot \mathrm{mL}^{-1}$ is classified as weak. Therefore, the current study showed that, regardless of treatments being applied as early and late, bush tea leaves and twigs had weak antimicrobial activity on tested bacteria strains based on MIC and MMC values. In addition, the results are in contrast with Osuagwu and Edeoga (2010), who reported significantly increased antimicrobial activity of the leaves of Ocimum gratissimum and Gongronema latifolium through fertilizer treatment. Further to the weak antimicrobial activity, the current results are in contrast to the report on widespread uses of bush tea as treatment of infection, suggesting that it may have strong antimicrobial activity (Tshivhandekano et al., 2014).

Various compounds such as norfenfluramine, phytol, caryophyllene, propylene glycol, $\alpha$-copaene, and squalene were detected in both early and late $\mathrm{N}$ applied bush tea. The compounds detected have different pharmaceutical properties. Norfenfluramine is generally used as an appetite depressant (Rothman et al., 2003), whereas phytol is an aromatic ingredient used in many fragrance compounds and it may be found in cosmetic and noncosmetic products (McGinty et al., 2010) Caryophyllene has been found to demonstrate selective antibacterial activity against $S$. aureus (Dahham et al., 2015). Propylene glycol is a commonly used solvent for oral, intravenous, and topical pharmaceutical agents (Lim et al., 2014). $\alpha$-Copaene is found in the inner bark essential oil of Kielmeyera coriacae Mart. and has remarkable antimicrobial activity against Gram-positive and Gram-negative bacteria (de Carla et al., 2015). Squalene is a naturally occurring polyprenyl compound known primarily for its key role as an intermediate in cholesterol synthesis. Its primary therapeutic use is as an adjunctive therapy in a variety of cancers (Kelly, 1999). The results are in support of the findings by Maedza et al. (2017), who reported that both qualitative and quantitative variation of bush tea chemical constituents were influenced by foliar application of different minerals. The results do not show any linear or quadratic increase of compounds based on the timing of $\mathrm{N}$ application or $\mathrm{N}$ application rates. Ibrahim et al. (2011) reported that application of $\mathrm{N}$ greater than $90 \mathrm{~kg} \cdot \mathrm{ha}^{-1}$ reduced the level of secondary metabolites produced on Labisia pumila.

In conclusion, except for antimicrobial activity, all other parameters recorded increased with increasing rates of $\mathrm{N}$ from 0 to $225 \mathrm{~kg} \cdot \mathrm{ha}^{-1}$ regardless of the timing of application. However, it was evident that early $\mathrm{N}$ application significantly improved most parameters recorded compared with late applied N. There were no significant differences between MIC and MMC values of bush tea leaves and twigs harvested from early and late applied $\mathrm{N}$. The MIC values ranged between 3.1 and $12.5 \mathrm{mg} \cdot \mathrm{mL}^{-1}$ whereas MMC values ranged between 6.3 and 25 $\mathrm{mg} \cdot \mathrm{mL}^{-1}$. The metabolite profiles using gas chromatography linked to mass spectrometry and liquid chromatography linked to mass spectrometry revealed variation in compounds found and their relative abundance based on level of applied $\mathrm{N}$ and timing of $\mathrm{N}$ application. The major compounds found were norfenfluramine, phytol, caryophyllene, propylene glycol, $\alpha$-copaene and squalene.

\section{Literature Cited}

Anon. 1972. Technicon Auto Analyser. Ind. Method. 2:98-70W.

Baranauskiene, R., P.R. Venskutonis, P. Viskelis, and E. Dambrauskiene. 2003. Influence of $\mathrm{N}$ fertilizers on yield and composition of thyme (Thymus vulgaris). J. Agr. Food Chem. 51:7751-7758.

Biesiada, A., A. Sokół-Łẹtowska, and A. Kucharska. 2008. The effect of $\mathrm{N}$ fertilization on yielding and antioxidant activity of lavender (Lavandula angustifolia Mill.). Acta Sci. Pol. Hortorum Cultus 7:33-40.

Bryant, J.P., F.S. Chapin, and D.R. Klein. 1983. Carbon/nutrient balance of boreal plant in relation to vertebrate herbivory. Oikos 40:357-368.

Cechin, I. and T.D. Fumis. 2004. Effect of N supply on growth and photosynthesis of sunflower plants grown in the greenhouse. Plant Sci. 166:1379-1385

Chabeli, P.M., F.N. Mudau, P.W. Mashela, and P. Soundy. 2008. Effects of N, phosphorus and potassium nutrition on seasonal tannin content of bush tea (Athrixia phylicoides DC). SA. J. Plant Soil. 25:79-83.

Chellan, N., D. De Beer, C. Muller, E. Joubert, and J. Louw. 2008. A toxicological assessment of Athrixia phylicoides aqueous extract following sub-chronic ingestion in a rat model. Hum. Exp. Toxicol. 27:819-825.

Cohen, M.A., M.D. Husband, S.L. Yoder, J.W. Gage, and G.E. Roland. 1998. Bacterial eradication by clinafloxacin, CI-990, and ciprofloxacin employing $\mathrm{MBC}$ test, in-vitro time kill and in-vivo time-kill studies. J. Antimicrob. Chemother. 41:605-614.

Dahham, S.S., M.T. Yasser, M.A. Iqbal, M.B.K. Ahamed, M.O. Ezzat, A.S.A. Majid, and A.M.S.A. Majid. 2015. The anticancer, antioxidant and antimicrobial properties of the sesquiterpene $\beta$-caryophyllene from the essential oil of Aquilaria crassna. Molecules 20:1180811829

de Carla, M.M., E.A. do Nascimento, S.A.L. de Morais, A. de Oliveira, R.L.C.S. Cunha, M.M Martins, C.H.G. Martins, T.S. Moreas, P.V. Rodrigues, C.V. da Silva, and F.J.T. de Aquino. 2015. Chemical constituents and evaluation of antimicrobial and cytotoxic activities of Kielmeyeracoriacea Mart. \& Zucc. essential oils. Evidence-Based Complementary and Alternative Medicine 2015:1-9.

Dey, S.K., D. Banerjee, S. Chattapadhyay, and K.B. Karmakar. 2010. Antimicrobial activities of some medicinal plants of West Bengal. Intl. J. Pharma Bio. Sci. 1:1-10.

Du Toit, R., Y. Volsteedt, and Z. Apostolides. 2001. Comparison of the antioxidant content of fruits, vegetables and teas measured as vitamin C equivalents. Toxicology 166:63-69.

Eloff, J.N. 1998. A sensitive and quick microplate method to determine the minimal inhibitory concentration of plant extracts for bacteria. Planta Med. 64:711-713.

Hamid, F.S., T. Ahmad, A. Waheed, N. Ahmad, and S. Aslam. 2014. Effect of different levels of $\mathrm{N}$ on the chemical composition of tea $(C$. sinensis $\mathrm{L}$.) grown at higher altitude. J. Mater. Environ. Sci. 5:73-80.

Hamilton, J.G., A.R. Zangerl, E.H. DeLucia, and M.R. Berenbaum. 2001. The carbon-nutrient balance: Its rise and fall. Ecol. Lett. 4:86-95. 
Hanlon, E.A., J.G. Gonzalez, and J.M. Bartos. 1994. IFAS extension soil testing laboratory chemical procedure and training manual. Fla. Coop. Ext. Serv. Circ.

Ibrahim, M.H., H.Z.E. Jaafar, A. Rahmat, and Z.A. Rahman. 2011. Effects of $\mathrm{N}$ fertilization on synthesis of primary and secondary metabolites in three varieties of Kacip fatimah (Labisia pumila Blume). Intl. J. Mol. Sci. 12:5238-5254.

Kelly, G.S. 1999. Squalene and its potential clinical uses. Altern. Med. Rev. 4:29-36.

Lawlor, D.W. 2002. Carbon and $\mathrm{N}$ assimilation in relation to yield: Mechanisms are the key to understanding production systems. J. Expt. Bot. 53:773-787.

Lim, T.Y., R.L. Poole, and N.M. Pageler. 2014. Propylene glycol toxicity in children. J. Pediatr. Pharmacol. Ther. 19:277-282.

Liu, D., W. Liu, D. Zhu, M. Geng, W. Zhou, and T. Yang. 2010. Nitrogen effects on total flavonoids, chlorogenic acid, and antioxidant activity of the medicinal plant Chrysanthemum morifolium. J. Plant Nutr. Soil Sci. 173:268-274.

Locascio, S.J., W.J. Wiltbank, D.D. Gull, and D.N. Maynard. 1984. Fruit and vegetable quality as affected by $\mathrm{N}$ nutrition, p. 617-641. In R.D. Hauck (ed.). $\mathrm{N}$ in crop production. American Society of Agronomy, Madison, WI.

Maedza, K.V., M. Nkomo, W. Ngezimana, N.P. Makunga, and F.N. Mudau. 2017. Response of phytochemicals in bush tea (Athrixia phylicoides DC.) as influenced by selected micronutrients. HortScience 52:965-971.

Martinez-Ballestra, M.C., L. Lopez-Perez, M. Hernandez, C. Lopez-Berenguer, N. FernandezGarcia, and M. Carvajal. 2008. Agricultural practices for enhanced human health. Phytochem. Rev. 7:251-260.

Maudu, M.E., F.N. Mudau, and I.K. Mariga. 2012. Quality profiles of cultivated and wild bush Tea (Athrixia phylicoides) harvested at various phenological stages. Intl. J. Agr. Biol. 14: 552-556.

Mavundza, E.J., T.E. Tshikalange, N. Lall, A.A. Hussein, F.N. Mudau, and J.J.M. Meyer. 2010. Antioxidant activity and cytotoxicity effect of flavonoids isolated from Athrixia phylicoides. J. Med. Plants Res. 4:2583-2586.

McGinty, D., C.S. Letizia, and A.M. Api. 2010. Fragrance material review on phytol. Food Chem. Toxicol. 48:S59-S63.

Mogotlane, I.D., F.N. Mudau, P.W. Mashela, and P. Soundy. 2007. Seasonal responses of total antioxidant contents in cultivated bush tea (Athrixia phylicoides L.) leaf to fertilizer rates. Med. Aromat. Plant Sci. Biotechnol. 1:77-79.

Mohammed, S. and A.F. Manan. 2015. Analysis of total phenolics, tannins and flavonoids from Moringa oleifera seed extract. J. Chem. Pharm. Res. 7:132-135.
Mudau, F.N., P. Soundy, and E.S. Du Toit. 2005. Plant growth and development of bush tea as affected by $\mathrm{N}$, phosphorus and potassium nutrition. HortScience 40:1898-1901.

Mudau, F.N., P. Soundy, and E.S. Du Toit. 2007. $\mathrm{N}$, phosphorus, and potassium nutrition increases growth and total polyphenol concentrations of bush tea in a shaded nursery environment. HortTechnology 17:107-110.

Mudau, F.N., P. Soundy, E.S. Du Toit, and J. Olivier. 2006. Variation in polyphenolic content of Athrixia phylicoides (L.) (bush tea) leaf with season and $\mathrm{N}$ application. SA. J. Bot. 72:398-402.

Musarurwa, H.T., J.V. Staden, and N.P. Makunga. 2010 . In vitro seed germination and cultivation of the aromatic medicinal Salvia stenophylla (Burch. Ex Benth.) provides an alternative source of $\alpha$-bisabolol. Plant Growth Regul. 61:287-295.

Nchabeleng, L., K.I. Mariga, W. Ngezimana, and F.N. Mudau. 2013. Bush tea (Athrixia phylicoides DC.) success stories in South Africa: A review. ESci. J. Crop Prod. 2:37-43.

Nchabeleng, L., F.N. Mudau, and I.K. Mariga. 2012. Effects of chemical composition of wild bush tea (Athrixia phylicoides DC.) growing at locations differing in altitude, climate and edaphic factors. J. Med. Plants Res. 6:1662-1666.

Nitao, J.K., A.R. Zangerl, and M.R. Berenbaum. 2002. CNB: Requiescat in pace? Oikos 8:540 546.

Njogu, R.N.E., D.K. Kariuki, D.M. Kamau, and F.N. Wachira. 2014. Effects of foliar fertilizer application on quality of tea (Camellia sinensis) grown in the Kenyan highlands. Amer. J. Plant Sci. 5:2707-2715.

Okano, K., K. Ghutani, and K. Matsao. 1997. Suitable level of $\mathrm{N}$ fertilization for tea (Camellia sinensis L.) and accumulation of free amino acids. J. Crop Sci. 66:279-289.

Osuagwu, G.G.E. and H.O. Edeoga. 2010. Effect of fertilizer treatment on the antimicrobial activity of the leaf of Ocimum gratissimum (L.) and Gongronema latifolium (Benth). Afr. J. Biotechnol. 9:8918-8922.

Owour, P.O. 1989. Black tea quality: Effects of some agronomic practices tea quality. Tea (Nairobi) 10:134-136.

Owour, P.O. and H.O. Odhiambo. 1994. Response of some black tea quality parameters to $\mathrm{N}$ fertilizer rates and plucking frequencies. J. Sci. Food Agr. 66:555-561.

Palumbo, M.J., F.E. Putz, and S.T. Talcott. 2007. N fertilizer and gender effects on the secondary metabolism of yaupon, a caffeine-containing North American holly. Ecophysiol. Oecol. 151:1-9.

Patel, V.R., P.R. Patel, and S.S. Kajal. 2010. Antioxidant activity of some selected medicinal plants in western region of India. Adv. Biol. Res. (Faisalabad) 4:23-26.

Rothman, R.B., R.D. Clark, J.S. Partilla, and M.H. Baumann. 2003. (+)-Fenfluramine and its major metabolite, $(+)$-norfenfluramine are potent substrates for norepinephrine transporters. J. Pharmacol. Exp. Ther. 305:1191-1199.

Ruan, J., R. Haerdter, and J. Gerendás. 2010. Impact of $\mathrm{N}$ supply on carbon/ $\mathrm{N}$ allocation: $\mathrm{A}$ case study on amino acids and catechins in green tea Camellia sinensis (L.) O. kuntze plants. Plant Biol. 12:724-734.

Sen, A. and A. Batra. 2012. Evaluation of antimicrobial activity of different solvent extracts of medicinal plant: Melia azedarach L. Intl. J. Curr. Pharm. Res. 4:67-73.

Sifola, M.I. and G. Barbieri. 2006. Growth, yield and essential oil content of three cultivars of basil grown under different levels of $\mathrm{N}$ in the field. Scientia Hort. 108:408-413.

Sitienei, K., P.G. Home, D.M. Kamau, and J.K. Wanyoko. 2013. The influence of fertilizer type and application rates in tea cultivation on $\mathrm{N}$ and potassium efficiencies. Afr. J. Agr. Res. 8:3770-3777.

Stefanelli, D., I. Goodwin, and R. Jones. 2010. Minimal $\mathrm{N}$ and water use in horticulture: Effects on quality and content of selected nutrients. Food Res. Intl. 43:1833-1843.

Thembo, K.M., H.F. Vismer, N.Z. Nyazema, W.C.A. Gelderblom, and D.R. Katerere. 2010 Antifungal activity of four weedy plant extracts against selected mycotoxigenic fungi. J. Appl. Microbiol. 109:1479-1486.

Tshivhandekano, I., W. Ngezimana, T.E. Tshikalange, N.P. Makunga, and F.N. Mudau. 2017. Nitrogen application influences quality, pharmacological activities and metabolite profiles of Athrixia phylicoides (bush tea) cultivated under greenhouse and field conditions. Acta Agri. Scand. Plant Soil Sci. 68:388-400.

Tshivhandekano, I., K. Ntushelo, W. Ngezimana, T.E. Tshikalange, and F.N. Mudau. 2014. Chemical compositions and antimicrobial activities of Athrixia phylicoides DC. (bush tea), Monsonia burkeana (special tea) and synergistic effects of both combined herbal teas. Asian Pac. J. Trop. Med. 7:448-453.

Wang, D., M.W. Maughan, J. Sun, X. Feng, F Miguez, D. Lee, and M.C. Dietze. 2012. Impact of $\mathrm{N}$ allocation on growth and photosynthesis of Miscanthus (Miscanthus giganteus). Glob. Change Biol. Bioenergy 6:688-697.

Watanabe, I. 1995. Effect of $\mathrm{N}$ fertilizer application at different stages on the quality of green tea. Soil Sci. Plant Nutr. 41:763-768.

Woldegebriel, D. 2007. Levels of essential and non-essential metals in commercially available Ethiopian black teas. Addis Ababa University, Ethiopia, MS thesis. 